\title{
The Implication of Residual Bacterial Isolates from Port Harcourt Waters
}

\author{
Prince Chinonso Nnadozie \\ Department of Microbiology, Faculty of Biological Sciences, College of Natural and Applied Sciences, University of Port Harcourt, Port \\ Harcourt, Rivers State, Nigeria
}

\section{Email address: \\ princemakat@yahoo.co.uk}

\section{To cite this article:}

Prince Chinonso Nnadozie. The Implication of Residual Bacterial Isolates from Port Harcourt Waters. International Journal of Environmental Monitoring and Analysis. Vol. 3, No. 5, 2015, pp. 312-316. doi: 10.11648/j.ijema.20150305.21

\begin{abstract}
The implication of residual bacterial isolates from two Port Harcourt waters: Abonnema Wharf (A) and Tourist Beach (B) were investigated in this study. A total of twelve (12) bacterial genera were isolated and mostly, which are of great public health concern, and are the cause of Enteric diseases in humans. Bacterial species was more diverse at B than A. Faecal coliforms were found as abundant species beyond regulatory permissible limits in the waters, indicating Pollution of the aquatic systems. The enumeration method employed was the Membrane filtration, where the residues were incubated at $35^{\circ} \mathrm{C}$ for isolation of total coliforms and $44.5^{\circ} \mathrm{C}$ for Faecal coliform for $24-48$ hours. Sewage contamination from humans and animals excrements, erosion/run-off, industrial effluents and oil spillage may have profound effect on the waters studied. The result of the study is a wake-up call for community involvement to protect water bodies and supplies from Pollution and to perform basic local surveillance and maintenance of water and sanitation systems.
\end{abstract}

Keywords: Enteric Diseases, Faecal Coliforms, Pollution, Membrane Filtration

\section{Introduction}

Beyond its importance for human consumption, it has been rightly asserted that water serves many purposes which include: acting as a source of fluid for man and animals; a medium for recreational activities such as fishing, boat-racing and swimming; a means of transportation through rivers and oceans; an agent for cleansing and cooling the body, objects or the environment; an agricultural irrigant; an adjunct to innumerable industrial processes; a conveyor for the disposal of human and industrial wastes; a medium systems of heating and air conditioning; and a means of extinguishing fire [7, 12]. Water is also a source of energy for man in hydroelectricity systems or as streams for driving turbines for the production of electricity.

Cheesbrough [5] noted that, Good quality water is odourless, colourless and tasteless, free from faecal matter and harmful chemicals. Therefore, any water not in agreement with the description above is considered unsafe for drinking.

Over many decades, a number of studies have attempted to correlate the incidence of water-borne and water associated diseases with water supply availability (quantity and accessibility) and the quality of water. Water pollution has tremendous harmful effect on humans, animals and other aquatic organisms. It arises from human, natural and industrial activities. Eroding of soil and natural vegetation, discharging wastes and effluents from sewage treatment plants, run-off from chemical fertilizers and pesticides, as well as oil and lube spillage in the coastal area from the operation of sea and river ports into water bodies contribute to the greatest threat to water quality especially in the Niger Delta region of Nigeria [2, $10,11,13]$.

Increased faecal Pollution in source water is a problem in developing as well as developed countries [4, 16]. When Faecal Coliform, bacteria which are present in large numbers in feaces and intestinal tracts of humans and other warm-blooded animals enter lakes, streams, rivers, oceans, and other water bodies from human and animal wastes, they grow or lie suspended in water or get deposited on the bed. Consequently, these result to the Pollution of water whereby the quality of the water deteriorates, affecting aquatic ecosystems.

There are two broad categories of water pollution: point source and non-point source. Point source water Pollution is emitted directly into a body of water. For instance, when a pipe from an industrial facility discharged effluents directly 
into a water body it is point source Pollution. In non-point source Pollution, pollutants are indirectly delivered into the water body through transport or environmental change. For example, this type occurs when fertilizers from agricultural farms are carried into a river by run-off via rain. Water which is of excellent quality, when it enters the distribution system (e.g., pipes, etc.) can undergo some deterioration before it reaches the consumer tap. Coliform organisms may gain access to the water, colonizing and multiplying in it. Thus, when consumed by man or animal it may lead to infection or disease establishment.

However, it has been confirmed that a better water distribution leads to better health. Improperly treated or untreated water has been proved through bacteriological examination to be the medium by which water-borne pathogenic organisms such as those that causes typhoid fever (Salmonella spp.), cholera (Vibrio cholerae), urinary tract infection and gastroenteritis (Escherichia coli), gas gangrene (Clostridium spp.) and various bacterial dysentery (Shigella spp.) are transmitted [3, 15]. According to Jones [9], there are higher counts of bacterial population in surface water than the anoxic zones where the anaerobes and the facultative aerobes predominate and showed that there is a general tendency for bacterial number to decrease with the depth of waters. The presence of microorganisms on water surfaces can lead to algal bloom (eutrophication) and oxygen deficiency down the water column. Moreover, in any water body, the type and population of organisms present depends on factors such as: i). The type of soil over which the water flows. ii). The nutrient status of the water. iii).The depth of the water. iv).The amount of dissolved oxygen. v).The Temperature; and vi).The availability of sunlight.

\section{Bacteriological Evidence for Contamination}

The Coliform group of bacteria is used as an indicator for water analysis. They are not necessarily pathogenic, but their presence is indicative of water Pollution. They are the predominant organisms that are found in the intestinal tract of man and other animals. The term Coliform has no taxonomic status but it's simply a convenient working term used by microbiologist to describe a group of organisms that have the capacity to ferment lactose-based medium under certain conditions. Coliforms are facultatively anaerobic, Gram-negative, non-sporing rod-shaped bacteria that ferment lactose with acid and gas formation within 48 hours at $35^{\circ} \mathrm{C}$ [14].The group includes: E. coli, Enterobacter spp., Citrobacter spp., and Klebsiella spp.

Moreover, it has become evident that the Coliform organisms found in water do not all carry the same degree of faecal significance. Only one variety, E. coli appears to be exclusively faecal in nature and can grow at the more restrictive temperature of $44.5^{\circ} \mathrm{C}$. Environmental microbiologists have generally used indicator organisms as an index of possible water contamination by human pathogen. In a water body, the higher incidence of an indicator organism implies a higher level of Pollution in that system. i.e., a high level of indicator organism present demonstrates that recent heavy Pollution has taken place; and a low level of indicator organism, light Pollution or Pollution at some time in the past.

Prescott et al. and Gerba [8, 14] have underscored that for an organism to be a reliable indicator of contamination;

i. The indicator organisms must be suitable for the analysis of all types of water: Tap, rivers, ground, impounded, recreational, estuary, sea, and waste.

ii. The indicator organisms must be present whenever enteric pathogens are present.

iii. The indicator organism must survive longer than the hardiest enteric pathogen.

iv. The indicator organism must not reproduce in the contaminated water.

v. The assay procedure for the indicator must have great specificity; in other words, other bacteria must not give positive result.

vi. The test procedure must have high sensitivity and detect low levels of the indicator.

vii. The indicator organism must be harmless to humans.

viii. The level of the indicator organism in contaminated water must have some direct relationship to the degree of faecal Pollution.

ix. The testing method must be easy to perform.

\section{Aims/Objectives}

To isolate and characterize faecal and total coliforms in Abonnema Wharf and Tourist Beach Waters, in order to ascertain water quality and ensure the safety of people living within the area.

\section{Materials and Methods}

\subsection{Description of Sample Locations}

The study areas: Abonnema Wharf (A) and Tourist Beach (B) were all located in Port Harcourt, Rivers State, Niger Delta of Nigeria. Port Harcourt is one of the commercial hubs in Nigeria. It habours hundreds of industries, among which are predominantly multinational oil companies. According to Abu and Nnadozie [1], these waters empty into other rivers, estuaries and eventually into the Atlantic Ocean via the Bonny River. Within sites $A_{0}, A_{1}, A_{2}$, and $A_{3}$ is Abonnema market with its terminals close to the Wharf. Dredge pipes laid by mini-oil rigs surround the area. Sites $B_{0}, B_{1}, B_{2}$, and $B_{3}$ sustain a jetty adjoining the canteens, bars, and restaurants; galleria, and staff quarters of Tourist Beach. At the Abonnema Wharf, were cattles grazing on plants in the area.

\subsection{Collection of Samples}

The enumeration of faecal and total coliforms from Abonnema Wharf (A) and Tourist Beach (B) brackish waters $(1.0 \pm 0.1 \%$ salinity) in Port Harcourt involves aseptic collection of water samples from the two sample stations. A total of eight water samples were collected with a sterile screw-capped glass bottles from eight sites $\left(A_{0}, A_{1}, A_{2}, A_{3}, B_{0}\right.$, $B_{1}, B_{2}$ and $B_{3}$ ) located in the two sample locations. Four of the water samples obtained from sites $\left(A_{2}, A_{3}, B_{2}\right.$ and $\left.B_{3}\right)$ were 
aseptically collected after two weeks of the first collection from sites $\left(A_{0}, A_{1}, B_{0}\right.$, and $\left.B_{1}\right)$.

\subsection{Membrane Filtration Procedure}

The Membrane Filtration (MF) method was adopted in this study. In the MF procedure, membrane filter absorbent pads were each placed inside a sterile Petri-dish, and saturated with $2 \mathrm{ml}$ of Endo agar lactose-based medium. $100 \mathrm{ml}$ of water sample, each for the sample stations, was filtered through a membrane filter $(0.45 \mu \mathrm{m}$ pore size $)$ in duplicates. After which the filters (bearing the residue) was placed on the medium with aid of sterile forceps. The Petri dishes were inverted and incubated for $24-48$ hours at $35 \pm 0.5^{\circ} \mathrm{C}$ for total coliform and at $44 \pm 0.5^{\circ} \mathrm{C}$ for faecal coliform. After 48 hours of incubation, colonies $(20-200)$ were observed and counted.

Standard procedures are followed during media preparations/sterilization and biochemical tests

The Coliform density of the water samples are based upon the membrane filter count within the $20-200$ Coliform colony range and calculated thus:

$$
\text { Total Coliform (TC)or Faecal Coliform (FC) count per } 100 \mathrm{ml}=\frac{\text { Coliform colonies counted at } 35 \text { or } 44.5^{\mathrm{o}} \mathrm{C}}{\text { Volume of sample filtered }(\mathrm{ml})} \times \frac{100}{1}
$$

The arithmetic mean of TC or FC count per $100 \mathrm{ml}$ (i.e., in duplicate of $100 \mathrm{ml}$ portions of the samples) is calculated as described by USEPA [17]:

Total Coliform (TC) or Faecal Coliform (FC) count per volume filtered in $\mathrm{ml}=$

$$
\text { (Number of colonies on MF }-1+\text { Number of colonies on MF }-2 \text { ) } \times 100
$$

$\overline{\text { (Volume in } \mathrm{ml} \text { of sample filtered via MF }-1+\text { Volume in } \mathrm{ml} \text { of sample filtered via MF }-2 \text { ) }}$

Or,

The arithmetic mean of TC or FC count per volume filtered in $\mathrm{ml}=$

$\underline{\text { TC or FC count per vol. filtered in } \mathrm{ml} \text { for MF }-1+\text { TC or FC count per vol. filtered in ml for MF }-2}$

\section{Results and Discussion}

The result of the analysis showed the proliferation of bacterial species in the water bodies. The total coliform (TC) for $\mathrm{A}$ and $\mathrm{B}$ as shown in Table 1 ranged from $4.05 \times 10^{1}-1.77$ x $10^{2} \mathrm{CFU} / 100 \mathrm{ml}$ and $5.60 \times 10^{1}-1.96 \times 10^{2} \mathrm{CFU} / 100 \mathrm{ml}$ respectively. The faecal coliform count ranged from $2.25 \times 10^{1}$ $-1.48 \times 10^{2} \mathrm{CFU} / 100 \mathrm{ml}$ and $7.3 \times 10^{1}-1.88 \times 10^{2}$ $\mathrm{CFU} / 100 \mathrm{ml}$ for $\mathrm{A}$ and $\mathrm{B}$ respectively. These values entail Pollution of the water bodies and they are above regulatory permissible limits for water quality.

The $\mathrm{pH}$ of the water bodies ranged from $5.6-6.8$ (A) and $5.9-9.5$ (B) which are contrary to the World Health Organization prescribed Limit of $6.5-8.5$ [1].

The result revealed that highest Pollution occurs at sites $\mathrm{B}_{0}$ (for TC) and $\mathrm{B}_{1}$ (for FC); while at sites $\mathrm{A}_{0}$ (for FC) and $\mathrm{B}_{3}$ (for TC) lowest Pollution occurs. Microorganisms such as Klebsiella pneumoniae, Pseudomonas spp., Staphylococcus aureus, Proteus spp., and Bacillus spp. were isolated from sites $\mathrm{A}_{1}, \mathrm{~A}_{2}, \mathrm{~B}_{0}$ and $\mathrm{B}_{3}$. At sites $\mathrm{A}_{1}, \mathrm{~A}_{0}$ and $\mathrm{B}_{1}$ are Citrobacter spp., Vibrio spp. and Salmonella spp. Serratia spp., Enterobacter spp. and Shigella spp. are found at site $\mathrm{A}_{3}$ and $\mathrm{B}_{2}$. In this study, some bacteria did not occur in the sites as previously found. For instance, Enterococcus faecalis that was found only at site $\mathrm{B}_{3}$ [1] was not isolated from the present samples. This may be as a result of seasonal changes, spatial distribution of bacteria, and varying degree of human/animal and industrial activities/influence on the ecosystem. E. coli is present in all the sites studied. The increasing presence of $E$. coli isolated from the different sampling sites reflects the degree of contamination by faecal matter. The current level of Faecal coliforms in Abonnema Wharf (A) and Tourist Beach (B) waters suggest that the waters are not good for domestic use and unfit for human consumption. With the highest Faecal coliform count in B-water, it is more polluted than A-water as also reported [1].

With the poor sanitation, unhygienic conditions, and overcrowding it contributes to the incidence rate of bacteria and sudden presence of new species (such as Serratia spp. and Vibrio spp.) that was recently not observed on the waters [1]. The presence of enteric bacteria and Bacillus spp. may reveal contamination by sewage (from humans and animals excrements) and run-off (from soil during the raining season) respectively. Industrial effluents and oil spillage may have profound effect on the waters due to the fact that Pseudomonas spp. and some other priority microbial cells are present in the waters.

The methodology (MF) adopted may be the reason for wide discovery of many bacterial cells in the water. This is because unlike the Multiple Tube Fermentation method, the MF method allows an appreciable volume of water to be filtered; and it has been recommended for its accuracy and speed of result [6].

The biochemical tests (Table 2) revealed the presence of lactose fermenters such as $E$. coli (see also Fig. 1), $K$. pneumoniae, Citrobacter spp. and Enterobacter spp. with the characteristics red and pink colonies on MacConkey agar; while the non-lactose fermenters (e.g. Samonella spp., Shigella spp., Vibrio spp., Pseudomonas spp. and Proteus spp.) show colourless colonies on MacConkey agar. E. coli 
characteristic colonies on Endo agar appears pink to dark-red with a unique metallic green sheen. Colonies on Xylose Lysine Deoxycholate agar (XLD) show pink-red colonies, with some showing black colonies. This confirms the presence of Samonella spp. (with black centres) and Shigella spp. (without black centres). The presences of yellow colonies on Thiosulphate Citrate Bile Salt Sucrose agar (TCBS) plates after overnight incubation at $35^{\circ} \mathrm{C}$ indicates that Vibrio spp. thrive in the waters.

Table 1. Total Coliforms (Tc) and Faecal Coliform (Fc) Counts Per 100ml of Water Samples.

\begin{tabular}{lll}
\hline Samples & $\begin{array}{l}\text { Total Coliforms } / \mathbf{1 0 0 m l} \\
\text { (TC) }\end{array}$ & $\begin{array}{l}\text { Faecal Coliforms } / \mathbf{1 0 0 m l} \\
(\text { FC) }\end{array}$ \\
\hline $\mathrm{A}_{0}$ & $4.05 \times 10^{1}$ & $3.20 \times 10^{1}$ \\
$\mathrm{~A}_{1}$ & $1.14 \times 10^{2}$ & $1.31 \times 10^{2}$ \\
$\mathrm{~A}_{2}$ & $6.15 \times 10^{1}$ & $7.65 \times 10^{1}$ \\
$\mathrm{~A}_{3}$ & $1.77 \times 10^{2}$ & $1.48 \times 10^{2}$ \\
$\mathrm{~B}_{0}$ & $1.96 \times 10^{2}$ & $1.57 \times 10^{2}$ \\
$\mathrm{~B}_{1}$ & $1.93 \times 10^{2}$ & $1.88 \times 10^{2}$ \\
$\mathrm{~B}_{2}$ & $1.07 \times 10^{2}$ & $1.27 \times 10^{2}$ \\
$\mathrm{~B}_{3}$ & $5.60 \times 10^{1}$ & $2.25 \times 10^{1}$ \\
\hline
\end{tabular}<smiles>NC(Cc1c[nH]c2ccccc12)C(=O)O</smiles>

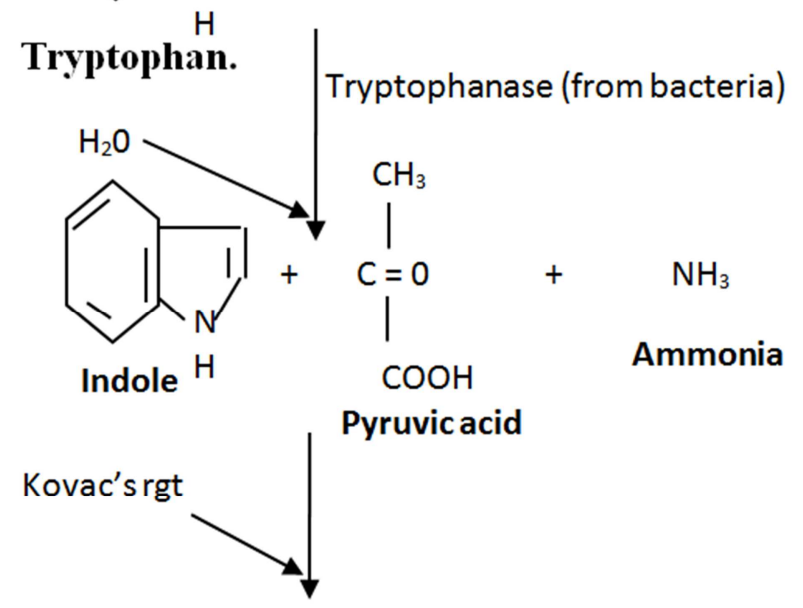

Red Colouration

Figure 1. Biochemical Reaction of Indole indicating presence of E. coli.

Table 2. Staining Reaction, Motility Test and Biochemical Test Carried Out on Various Isolates from Abonnema Wharf (A) and Tourist Beach (B) Water Samples.

\begin{tabular}{|c|c|c|c|c|c|c|c|c|c|c|c|c|c|c|c|}
\hline Isolates & $\begin{array}{l}\text { Gram } \\
\text { Reaction }\end{array}$ & $\begin{array}{l}\text { Cell } \\
\text { Morphology }\end{array}$ & IND & MR & VP & CIT & CAT & OXID & COAG & UREA & LAC & GLU & $\mathbf{H}_{2} \mathbf{S}$ & LDC & MOT \\
\hline E. coli & - & Rod & + & + & - & - & + & - & - & - & + & + & - & + & + \\
\hline K. pneumonia & - & Rod & - & - & - & + & + & - & - & + & + & + & - & + & - \\
\hline Citrobacter spp. & - & Rod & - & + & - & + & + & - & - & - & + & + & + & - & + \\
\hline Enterobacter spp. & - & Rod & - & - & + & + & + & - & - & - & + & + & - & + & + \\
\hline Vibrio spp. & - & Rod & + & - & - & + & + & + & - & - & - & + & - & + & + \\
\hline Pseudomonas spp. & - & Rod & - & - & - & + & + & + & - & - & - & + & + & - & + \\
\hline Proteus spp. & - & Rod & - & + & - & - & + & - & - & + & - & + & + & - & + \\
\hline Salmonella spp. & - & Rod & - & + & - & - & + & - & - & - & - & + & + & + & + \\
\hline Shigella spp. & - & Rod & - & + & - & - & + & - & - & - & - & + & - & - & - \\
\hline Serratia spp. & - & Rod & - & - & - & + & - & - & - & + & - & + & - & + & + \\
\hline Bacillus spp. & + & Rod & - & - & + & + & + & - & - & - & - & + & - & - & - \\
\hline S. aureus & + & Cocci & - & - & + & + & + & - & + & - & + & + & - & + & - \\
\hline
\end{tabular}

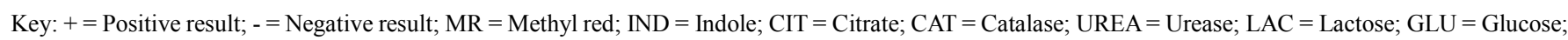
$\mathrm{COAG}=$ Coagulase; OXID =Oxidase; $\mathrm{H} 2 \mathrm{~S}=$ Hydrogen sulphide; VP= Voges poskauer; LDC = Lysine decarboxylase; and MOT = Motility.

\section{Conclusion}

Conclusively, this study revealed that Abonnema Wharf and Tourist Beach are polluted with most virulent etiological agents capable of causing water-related infections or diseases in developing countries as well as the developed. The continual existence of infective biological agents in the waters is a wake-up call for community involvement to protect water bodies and supplies from Pollution and to perform basic local surveillance and maintenance of water and sanitation systems.

\section{Recommendations}

I recommend that the Federal Government of Nigeria agencies saddled with the responsibility of water protection and municipal water supply should conduct regular check and monitor different kinds of waters people consume on a daily basis.

The management of A and B should build drainage systems in order to minimize the inflow of eroded water from land to the waters. This would abate the consequent role of soil as a reservoir of some of the enteric microorganisms isolated from the waters. The contamination source which was also attributed to a massive cattle-rearing activity in the area should be checkmated.

Foreign and local special intervention funds should be made available for the core purpose of treating the water bodies studied.

The recommendations made by $\mathrm{Abu}$ and Nnadozie [1] should be look into in order to address the rising spate of Pollution in the Niger Delta of Nigeria. 


\section{Acknowledgments}

I wish to express my profound gratitude to the Almighty God, who has provided my parents, Chief and Lolo M. O. Nnadozie with the resources to support this research work. I also wish to thank Prof. Gideon Abu and Prof. E. J. Okereke of the University of Port Harcourt for their contributions to this great work.

\section{References}

[1] Abu, G. O. and Nnadozie, P. C. (2015) Faecal Pollution and Enteric Bacterial Distribution in Port Harcourt Waters: A Case Study of Abonnema Wharf and Tourist Beach Waters. Int. J. of Sc. Res. and Educ., 3 (9): 4462 - 4472, http://ijsae.in/ijsaeems/index.php/ijsa e/article/view/967,doi:http://dx.doi.o $\mathrm{rg} / 10.18535 / \mathrm{ijsre} / \mathrm{v} 3 \mathrm{i} 9.17$.

[2] Alam, M. N., Elahi, F., Didar, U. L., and Alam, M. D. (2006) Risk and Water Quality Assessment Overview of River Sitalakhya in Bangladesh. Academic Open Internet J. 19 ISSN 1311- 4360 [online] http://www.acadjournal.com.

[3] Archibong, A. E. (1986), Bacteriological Examination of Tap and Stream Water from Five Villages in Port Harcourt, University of Port Harcourt, Nigeria. Pg. 27.

[4] Bezuidenhout, C. C., Mthembu, C., Puckree, T., and Lin, J. (2002) Microbiological Evaluation of the Mhlathuze River, Kwazulu-Natal (RSA). Water SA. 28(3): 281- 286.

[5] Cheesbrough, M. (1984) Medical Laboratory Manual for Tropical Countries. $2^{\text {nd }}$ ed. Butter Worth- Heinman Ltd. Pp. 206 $-231$.

[6] Cheesbrough, M. (2006) District Laboratory Practice in Tropical Countries, Part 2. $2^{\text {nd }}$ Ed., Cambridge University Press publication, South Africa, pp. $1-434$.
[7] Duncan, J. W. K. (1985), Water Supplies and Health of Africans, Principles and Practice of Community Health in Africa, Pp. 88 - 97.

[8] Gerba, C. P. (2000) Indicator microorganisms, Environmental Microbiology, Chapter 23, Pp. 485 - 489.

[9] Jones, G. J. (1971), Studies of Fresh Water Bacteria, Factors which Influence their Population and Activities, J. of Ecology. Pp. $593-661$.

[10] Kifferstein, B. and Krantz, D (1998) Water Pollution and Society. [online]http://www.umich.edu/gs265/ society/waterpollution.html

[11] Morrison, G., Fatoki, O. S., Persson, L., and Ekberg, A. (2001) Assessment of the Impact of Point Source Pollution from the Keiskammahoek Sewage Treatment Plant on the Keiskamma River. Water SA. 27(4):475 - 480.

[12] Nduka, O. (1985) Aquatic and Waste Microbiology. Published by Fourth Dimension Publishing Co., Ltd, Enugu, Nigeria. Pp. $1-127$.

[13] Odokuma, L.O., and Okpokwasili, G. C. (1997) Seasonal Influences of the Organic Pollution Monitoring of the New Calabar River, Nigeria. Environ. Monitor. Assess. 45:43 - 56.

[14] Prescott, L. M., Harley, J. P., and Klein, D. A. (2008), Microbiology, $6^{\text {th }}$ ed., McGraw-Hill, New York, USA, Pg. 26, $1050-1053$.

[15] Santamaria, J. and Toranzos, G. A. (2003) Enteric Pathogen and Soil: A Short Review. Int. Microbiol. 6: 5 - 9. DOI: 10.1007/s10123-003-0096-1.

[16] Sinton, L. W., Donnison, A. M., and Hastie, C. M. (1993) Faecal Streptococci as Faecal Pollution Indicators: a review.11.sanitary significance, survival, and use. N.Z .J. Mar. Freshwater Res. 27:117 - 137.

[17] USEPA (1986) Total Coliform: Membrane Filter Technique. Method 9132, Pp. 1 - 13. 